earthwork and outer ditch. Also, within the earthwork there are round patches of chalk. These have been placed thele to mark the sites of holes which were discovered two years ago. We have named them Aubrey holes after an investigator of that name who, in 1666 , hinted at their possible existence, but did not find them. Only about half the number has been opened, but we have ascertained that there are fiftysix. They are evenly spaced at 16 feet apart, and there can be little doubt that they once held stones forming a continuous circle, older than the existing monument. The old circle stones would have been rough, undressed ones, and perhaps of about the date of Avebury. When the present monument was built it is possible that the rough stones were taken out and dressed and erected as the smaller stones now visible, as it is not likely they would have been wasted, and, moreover, their number corresponds nearly with that of the holes.

The empty holes appear to have been used for human interments, as nearly all of them contained cremated bones. Only a portion of the cremated remains of a body are found in each hole and in one instance only fourteen pieces of charred bone. The actual cremations must have been carried out elsewhere and the remains brought here for interment, for up to the present time no sign of a large fire has been met with ; and the burning of only one body would require several tons of wood to calcine it thoroughly; and the quantity of black wood ashes remaining, being indestructible, would have been noticed. These interments occurred in Neolithic times, as chips were found amongst the debris in the holes, and in one instance an implement maker had thrown all his discarded chips into a hole.

Lately I have been excavating the ditch outside the earthwork. It was probably the first work done here, and from it I trust to get a continuous linking up of periods from the earliest to the latest. So far this work has not been very profitable, but has given a good result in showing that a very long time must have elapsed between making the ditch and rampart and the building of Stonehenge. It seems to have fallen into neglect, and was nearly silted up when Stonehenge was built. This is conclusively shown by finding the masons' chips only I4 or I5 inches below the surface in the rubble covering the silt, where they cease abruptly, the silt containing no trace of anything relating to Stonehenge. It is devoid of any objects beyond occasional small fragments of animal bone, but when the bottom is reached at $4 \frac{1}{2}$ to $5 \frac{1}{2}$ feet below the surface, flint chips discarded by implement makers are found in great quantities, but rarely an actual implement. Many staghorn picks used in the excavation of the ditch are met with, and the upper parts of antlers cut off and thrown away when the picks were made.

This season I am again excavating the ditch, and this time on the north-east; to find out if it was a continuous circle or whether the avenue was made at that time or later, when Stonehenge was built, for I am inclined to think that there were two distinct periods here-an early one, when the circle of stones stood round the rampart, and a later one when this Stonehenge was built, with a considerable interval between them.

\title{
The Sense of Smell in Birds: a Debated Question.
}

$\mathrm{O}^{\mathrm{t}}$ RGANS of smell are present in birds as a class and are well developed in many species, but much doubt attaches to the nature and extent of their usefulness. The South American vultures and the petrels are noteworthy for the size of their olfactory chambers, and the Apteryx possesses a complicated nasal labyrinth and is peculiar in having its nostrils at the extreme tip of the beak. Yet even in cases like these the practical demonstration of a sense of smell is beset with difficulties, and the existing evidence is conflicting and largely inconclusive. It seems difficult, of course, to believe that the apparatus serves no purpose, especially where it is highly developed or is specialised along particular lines, but apart from the unsatisfactory quality of a priori arguments the alternative must be borne in mind that the organs may have some other function than a sense of smell of the kind with which we are subjectively familiar.

The sense of smell is notoriously acute in the majority of mammals. Although they are generally also well endowed with sight and hearing, it is by smell that they chiefly find their food and by smell that they receive the first warning of the proximity of enemies: the importance of approaching four-footed game upwind is a commonplace. In birds the case is obviously very different, for with them vision must certainly be given pride of place. Hearing, too, is very well developed in birds, and there is also often a delicate sense of touch-witness the bill of the snipe-and possibly some power of discriminating food by taste. It may be argued that a sense of smell would be less useful to birds than to mammals : the great distances from which some birds detect their prey seem practically prohibitive for any sense but vision, and the spaces of the upper air must form a much less favourable medium for scent than the ground winds on which mammals so greatly rely.

Like so many other problems of natural history, this question attracted the attention of Charles Darwin, and in "A Naturalist's Voyage Round the World" we read of the experiment which he made in a garden in Chile where twenty or thirty captured condors were tethered in a long row at the bottom of a wall. "Having folded up a piece of meat in white paper," he says, "I walked backwards and forwards, carrying it in my hand at a distance of about three yards from them, but no notice whatever was taken. I then threw it on the ground, within one yard of an old male bird; he looked at it for a moment with attention, but then regarded it no more. With a stick I pushed it closer and closer, until at last he touched it with his beak; the paper was instantly torn off with fury; at the same moment, every bird in the long row began struggling and flapping its wings. Under the same circumstances it would have been quite impossible to have deceived a dog." In the same place Darwin

$$
\text { NO. } 2746 \text {, VOL. IOg] }
$$


refers to the well-authenticated experiments of a $\mathrm{Mr}$. Bachmann with the American turkey-buzzard, another carrion-eating vulture and one in which highly developed olfactory nerves had been demonstrated by Owen. Portions of highly offensive offal were wrapped in thin canvas : the birds seemed unable to detect.the food even when eating pieces of meat which were in some cases strewn on the outside of the package, but as soon as a small rent was made for them in the canvas the prize was at once discovered.

Both before and since Darwin's day the question of the absence or presence of acute smelling powers in birds has been much discussed, and the negative view has been maintained by many ornithologists of repute. To this question Mr. J. H. Gurney now makes a welcome and interesting contribution in a recent paper "On the Sense of Smell Possessed by Birds" (Ibis, I922, Eleventh Series, iv, 225). After recounting the history of the discussion and making reference to the anatomical facts and experimental findings, he deals at length with the observational evidence in favour of the existence of an acute sense of smell in certain species. Among these the rook and some woodpeckers are cited on account of the accuracy with which they seem able to locate hidden grubs, below the ground in one case and beneath the tree-bark in the other. Various petrels are also mentioned, some of these being credited by good observers with the power, for instance, of detecting offal thrown overboard by fishing boats even in thick mist. Geese and ducks, too, have very frequently been thought to possess powers of smell, and in the Norfolk duckdecoys the watching decoyman customarily burns peat or the like to prevent the birds scenting him down-wind. Other birds, notably the great bustard, commonly forsake their nests if their eggs have been handled. The most striking case, however, is that of the vultures of different kinds which are familiar in many parts of the world. It is indeed difficult to explain on any other theory than that of scent how these birds of ill-omen should know when a death has occurred in a house, congregating on the roof as if in the hope of gaining access to the corpse which they cannot possibly have seen: the same faculty was traditional in this country as regards the raven, when that species was commoner than it is now. Against all this, however, there is a mass of testimony from naturalists and sportsmen that birds show little or no power of detecting the presence of an enemy, even if approaching down-wind, until either sight or hearing comes into play. The success with which bird photographers can conceal themselves close to birds' nests, for instance, is in marked contrast to the difficulty experienced in studying wild mammals. In the case of vultures, in particular, there is also the evidence of the experiments already quoted, and the experience of sportsmen in India that killed game is safe from these birds if left covered from view.

In view of the weakness of the evidence obtainable by direct observation, due to the difficulty of eliminating the possible action of the other senses under ordinary conditions, one would naturally look with hope to experimental methods. These, however, have not been altogether neglected, and the results have been disappointingly inconclusive. Bachmann's experiment, already quoted from Darwin, seems to be one of the best on record. Another essay was Dr. Alexander Hill's experiment (NATURE, February 2, 1905) with domestic Turkeys, to which he offered alternative dishes of the same food, one untainted and the other containing some such substance as asafœtida, essence of anise, or oil of lavender. The results were very unsatisfactory, the birds appearing to be indifferent not only to the smell but also to the taste of the noxious substances. In America, Dr. R. M. Strong has tried the effect of placing hidden food close to doves confined in boxes which could be regulated to admit or to exclude odours. Here again the results were negative, no notice being taken of the food by any of the birds. To these may perhaps be added the experiment carried out by Prof. Watson and Dr. Lashley on the noddy and sooty terns of the Tortugas Islands off the coast of Florida. These investigators were studying the homing faculties of breeding terns, and in some cases they tried the effect of sealing up the birds' nasal chambers with wax: here again no difference in behaviour was observable. This last experiment is of special interest because it had for its object the testing of the theory that the olfactory apparatus may function not as an organ of smell but as a mechanism for detecting the temperature or humidity of the wind and thus as an aid to directional guidance during prolonged flight.

There is, then, a well-developed olfactory apparatus in birds which one is reluctant to consider altogether ineffective, and there are instances of behaviour which are difficult to explain except on the supposition that an acute sense of smell exists in the species concerned. On the other hand, there is a greater mass of evidence of behaviour suggesting that the sense is not developed to any important extent, and the results of experiments-so far as they can be considered satisfactory at all-point in the same direction. It accordingly remains difficult to arrive at any definite judgment on the question, and scepticism as to the existence of any very efficient sense of smell in birds is probably still warranted. As Mr. Gurney says, the onus probandi rests with the upholders of the scenting theory.

\section{The Hull Meeting of the British Association.}

$\mathrm{T}$ is ninety-one years since the British Association for the Advancement of Science was founded, in Yorkshire, and it is sixty-nine years since the Association paid its single visit to Kingston-on-Hull. One prominent Hull citizen, the head of an important industry, who was present at the Hull meeting as a member is still living, but it is not anticipated that many others will remember the previous Hull meeting.
By the appointment of a strong executive committee and numerous sub-committees the arrangements for the Hull meeting are well in hand, and it is hoped that the attendance at Hull may exceed that at Edinburgh; everything possible is being done to attain that object.

Situated on the broad estuary of the Humber, at the junction of the river Hull, King Edward I., so long ago as 1299, saw the geographical advantages of the 